\title{
Leukotrienes inhibit early stages of HIV-1 infection in monocyte-derived microglia-like cells
}

\author{
Jonathan Bertin, Corinne Barat, Dave Bélanger and Michel J Tremblay*
}

\begin{abstract}
Background: Microglia are one of the main cell types to be productively infected by HIV-1 in the central nervous system (CNS). Leukotriene $B_{4}\left(L T B_{4}\right)$ and cysteinyl-leukotrienes such as $L T C_{4}$ are some of the proinflammatory molecules produced in infected individuals that contribute to neuroinflammation. We therefore sought to investigate the role of leukotrienes (LTS) in HIV-1 infection of microglial cells.
\end{abstract}

Methods: To evaluate the role of LTs on HIV-1 infection in the CNS, monocyte-derived microglial-like cells (MDMis) were utilized in this study. Leukotriene-treated MDMis were infected with either fully replicative brain-derived HIV-1 isolates (YU2) or R5-tropic luciferase-encoding particles in order to assess viral production and expression. The efficacy of various steps of the replication cycle was evaluated by means of p24 quantification by ELISA, luciferase activity determination and quantitative real-time polymerase chain reaction (RT-PCR).

Results: We report in this study that virus replication is reduced upon treatment of MDMis with $\mathrm{LTB}_{4}$ and $\mathrm{LTC}_{4}$. Additional experiments indicate that these proinflammatory molecules alter the $\mathrm{pH}$-independent entry and early post-fusion events of the viral life cycle. Indeed, LT treatment induced a diminution in integrated proviral DNA while reverse-transcribed viral products remained unaffected. Furthermore, decreased C-C chemokine receptor type 5 (CCR5) surface expression was observed in LT-treated MDMis. Finally, the effect of LTs on HIV-1 infection in MDMis appears to be mediated partly via a signal transduction pathway involving protein kinase $C$.

Conclusions: These data show for the first time that LTs influence microglial cell infection by HIV-1, and may be a factor in the control of viral load in the CNS.

Keywords: Central nervous system, Microglia, HIV-1, Leukotrienes

\section{Background}

Infection of the central nervous system (CNS) by human immunodeficiency virus type 1 (HIV-1) causes neurotoxicity and inflammatory disorders such as encephalitis and associated neurocognitive deficits [1]. Since the introduction of highly active antiretroviral therapy (HAART) as the standard of care for seropositive patients, the incidence of severe neurological complications caused by HIV-1 such as dementia has greatly diminished, but a more subtle form of CNS dysfunction known as minor cognitive and motor disorder has emerged [2]. Although a discordance between cerebrospinal fluid (CSF) and plasma viral load is often observed, sustained virus replication in the CNS despite

\footnotetext{
*Correspondence: michel.j.tremblay@crchul.ulaval.ca

Centre de Recherche en Infectiologie, RC709, Centre Hospitalier Universitaire de Québec-CHUL, 2705 Boul. Laurier, Québec, QC G1V 4G2, Canada
}

suppressive antiretroviral therapy correlates with acute or subacute neurological alterations [3-5]. Moreover, the viral strains present in the CNS may, over time, genetically differ from virus isolates circulating in peripheral blood [6]. Unsuppressed virus replication in the brain favors the emergence of drug-resistant viruses and the appearance of viral variants with reduced dependence for CD4, the primary cellular receptor for HIV-1 [7]. Nevertheless, some studies have shown that the level of CNS penetration in patients receiving HAART does not significantly influence clinical efficacy $[1,8]$, although this issue remains controversial [9].

Entry of HIV-1 into the CNS occurs very early after primary infection [10]. The Trojan horse model proposes that HIV-1 can cross the blood-brain barrier (BBB) through monocytes carrying virions and then be liberated into the CNS [11-13]. Also, it has been

\section{Biomed Central}


postulated that elevated concentrations of the bacterial endotoxin lipopolysaccharide (LPS) in the plasma of HIV-1-infected patients, in combination with several cytokines, viral proteins and eicosanoid lipid mediators, increase permeability of the $\mathrm{BBB}$, thus facilitating invasion of HIV-1 into the CNS $[11,14,15]$. There, perivascular macrophages and microglia, along with astrocytes to some extent, are the cells permissive to HIV-1 infection; they also act as long-lived viral reservoirs despite antiviral therapies $[6,16-20]$.

Leukotrienes (LTs), which are classified as eicosanoids, are among the first soluble factors produced by the innate immune system when challenged by an invading pathogen. These potent proinflammatory lipid mediators display strong vasoconstrictive, chemotactic and proliferative properties. They are associated with different inflammatory diseases, such as asthma, rhinitis and atherosclerosis. In stimulated cells, the enzyme 5-lipoxygenase (5-LO) initiates synthesis of LTs from arachidonic acid. A short-lived LT precursor, $\mathrm{LTA}_{4}$, is converted into either leukotriene $\mathrm{B}_{4}\left(\mathrm{LTB}_{4}\right)$ or cysteinyl-LTs (cysLTs), the latter includes $\mathrm{LTC}_{4}, \mathrm{LTD}_{4}$ and $\mathrm{LTE}_{4}$. CysLTs engage CysLT-1, CysLT-2 and GPR17 receptor subtypes, whereas $\mathrm{LTB}_{4}$ exerts its biological action by means of cell surface receptors denoted as BLT1 and BLT2, all of which belong to the family of G-proteincoupled receptors $[21,22]$. BLT1 is expressed primarily in leukocytes while BLT2 is expressed more ubiquitously $[23,24]$. It should be stated that both CysLT-1 and CysLT-2 are expressed in many cell types, including cells of the monocyte/macrophage lineage [25]. Engagement of LT receptors on microglia is associated with release of the multifunctional nucleotide adenosine-5'triphosphate (ATP) and of cysLTs [26]. Furthermore, the increase of LT synthesis in microglial cells following LT-receptor activation requires the intracellular second messenger p38 MAP kinase (MAPK) [27].

Several studies have reported that LTs, along with their cognate receptors, are expressed in the brain [22,26,28-35]. Moreover, in vitro cocultures of HIV-1infected monocytes and astroglia secrete high levels of eicosanoids such as $\mathrm{LTB}_{4}$ and $\mathrm{LTD}_{4}$, which largely contribute to neuroinflammation and neuronotoxicity [36]. In vivo, it has been reported that elevated amounts of $\mathrm{LTB}_{4}$ can be found in the CSF of patients with AIDS [37]. Moreover, recent studies have shown that increased levels of 5-LO and high concentrations of eicosanoids, including $\mathrm{LTB}_{4}$, are found in the brain of HIV-1 transgenic rats $[38,39]$. Moreover, it has been demonstrated that activated microglia can produce several proinflammatory cytokines, chemokines and certain eicosanoid metabolites [29,40-42]. In turn, chemotactic molecules secreted in neuropathologic conditions, such as LTs, contribute to the recruitment of potentially infected leukocytes (including monocytes and lymphocytes) into the CNS [43]. However, LTs have also been reported to indirectly exert anti-HIV-1 properties. For example, $\mathrm{LTB}_{4}$ induces the release by neutrophils of antimicrobial proteins, including $\alpha$-defensins, that inhibit HIV-1 infectivity [44,45].

We therefore tested whether LTs can modulate virus infection in human microglial cells, which are known to play a pivotal role in the neuropathogenesis of HIV-1. Studies were performed using a previously described experimental cell system based on primary human monocyte-derived microglial-like cells (MDMis). We report herein that $\mathrm{LTB}_{4}$ and $\mathrm{LTC}_{4}$ negatively modulate some early events in HIV-1 infection in MDMis and that this effect relies at least partly on protein kinase $C$ (PKC).

\section{Methods \\ Reagents}

$\mathrm{LTB}_{4}, \mathrm{LTC}_{4}$ and their respective less active metabolites (that is, $N$-acetyl $\mathrm{LTE}_{4}$ and 20 -carboxy-LTB 4 ) were all purchased from Cayman Chemical (Ann Arbor, MI, USA). Granulocyte macrophage colony-stimulating factor (GM-CSF) was a generous gift from Cangene (Winnipeg, Manitoba, Canada), whereas macrophage colonystimulating factor (M-CSF) was purchased from GenScript Corporation (Piscataway, NJ, USA). The luciferase activity assay was carried out using the D-luciferin reagent purchased from Thermo Fisher Scientific (Rockford, IL, USA). Slot blots to quantify substance P in cellfree supernatants were revealed with the Western lightning plus ECL purchased from PerkinElmer (Waltham, MA, USA). The PKC inhibitor bisindolylmaleimide IX (also called Ro318220) was obtained from EMD Chemicals (Gibbstown, NJ, USA). The two LT receptor antagonists LY293111 and Bay-u9773 were purchased from Cayman Chemical.

\section{Antibodies}

The anti-HIV-1 p24 hybridomas 31-90-25 and 183-H12$5 \mathrm{C}$ were obtained from the American Type Culture Collection (ATCC) (Manassas, VA, USA) and the NIH AIDS Repository Reagent Program (Bethesda, MD, USA), respectively. Antibodies were purified by using MAbTrap protein affinity columns according to the manufacturer's instructions (Amersham Pharmacia Biotech AB, Uppsala, Sweden). Differentiation of primary human monocytes into MDMis was assessed using an antibody specific for the ionized calcium binding adaptor protein 1 (IBA1) (Wako Chemical, Richmond, VA, USA) followed with a goat anti-rabbit antibody labeled with the Alexa Fluor $\left.{ }^{(}\right) 55$ dye (Molecular Probes, Eugene, OR, USA). Detection of substance $\mathrm{P}$ was assessed using the rabbit polyclonal anti-substance $\mathrm{P}$ 
antibody (Abbiotech, San Diego, CA, USA) and the horseradish peroxidase (HRP)-conjugated goat anti-rabbit antibody (Jackson Immunoresearch, West Grove, PA, USA). LT receptor expression was determined by flow cytometry using either a rabbit anti-cysLT2 antibody (Cayman Chemicals) followed by a goat anti-rabbit antibody conjugated with Alexa Fluor ${ }^{\circledR} 488$ (Molecular Probes) or a biotinylated anti-BLT1 antibody (Cayman Chemical) followed by a streptavidin-R-phycoerythrin conjugate (BD Bioscience, Mississauga, Canada). C-C chemokine receptor type 5 (CCR5) expression on MDMis was assessed using the R-phycoerythrin-conjugated anti-CCR5 antibody (clone 2D7) purchased from BD Bioscience.

\section{Plasmids}

The brain-derived full-length R5-tropic YU2 and X4using NL4-3 infectious molecular clones of HIV-1 were obtained through the AIDS Research and Reference Reagent Program (pYU2 from Dr Beatrice Hahn and Dr George Shaw and pNL4-3 from Dr Malcolm Martin) $[46,47]$. The pNL4-3Balenv is a full-length infectious molecular clone of HIV-1 (kindly provided by R Pomerantz, Thomas Jefferson University, Philadelphia, PA, USA) [48]. This virus is an R5-using viral strain where the NL4-3 env gene has been replaced with the env gene from the R5-tropic Bal variant. As for the NL4$3 L u c^{+} E n v^{-} R^{+}$vector, kindly provided by Dr NR Landau (NYU School of Medicine, New York, NY, USA), it produces envelope-deficient HIV-1 particles coding for the luciferase reporter gene. Single-cycle reporter viruses were pseudotyped with JR-FL envelope or vesicular stomatitis virus envelope glycoprotein G (VSV-G) leading to NL4-3Luc $E n v^{-} R^{+} / \mathrm{JR}-\mathrm{FL}$ and NL4-3Luc ${ }^{+} E n v^{-} R^{+} / \mathrm{VSV}-$ G pseudotypes, respectively. The R5-tropic envelopeencoding JR-FLenv vector was kindly supplied by Dr NR Landau, whereas pHCMV-G, which was obtained from the AIDS Repository Reagent Program, codes for the broad host-range VSV-G under the control of the human cytomegalovirus promoter.

\section{Cell culture}

In order to obtain astrocyte-conditioned medium (ACM), normal human astrocytes were cultured in astrocyte basal medium supplemented with astrocyte growth medium. Primary human astrocytes and media were purchased from Lonza (Walkersville, MD, USA). At $80 \%$ cellular confluence, the medium was harvested, filtered $(0.22 \mu \mathrm{m})$ and aliquoted. Aliquots of all passages were kept at $-80^{\circ} \mathrm{C}$ up to the tenth passage. This ACM was then tested to determine the optimal percentage for differentiating primary human monocytes into MDMis. Briefly, peripheral blood mononuclear cells (PBMCs) from healthy donors were isolated by Ficoll-Hypaque gradient (Wisent Inc., St-Bruno, Qc, Canada). Next, cells were plated at a final concentration of $1 \times 10^{7}$ cells $/ \mathrm{ml}$ in $75 \mathrm{~cm}^{2}$ flasks (BD Bioscience, Mississauga, $\mathrm{ON}$, Canada) for $2 \mathrm{~h}$ in order to separate by adherence monocytes from the other non-adherent cells. After washing with endotoxin-free phosphate-buffered saline (PBS) (Sigma-Aldrich, Oakville, ON, Canada), monocytes were cultured in complete RPMI-1640 medium (that is, RPMI supplemented with $10 \%$ heat-inactivated fetal bovine serum (FBS), $100 \mathrm{U} / \mathrm{ml}$ penicillin $\mathrm{G}$ and 100 $\mu \mathrm{g} / \mathrm{ml}$ streptomycin) in the presence of M-CSF (10 $\mathrm{ng} /$ $\mathrm{ml})$ and GM-CSF $(1 \mathrm{ng} / \mathrm{ml})$ for 2 days. Cells were then recovered with a soft cell scraper and plated in 24-well plates (BD Bioscience, Mississauga, ON, Canada) at a final concentration of $1 \times 10^{5}$ cells per well in complete RPMI-1640 medium supplemented with M-CSF (10 ng/ $\mathrm{ml})$, GM-CSF (1 ng/ml) and with (to obtain MDMis) or without (to be used as control cells) an optimized percentage of ACM (ranging from 25\% to 35\%). To confirm that ACM-treated monocytes display a cell phenotype resembling microglial-like cells, after 14 days of exposure to ACM the morphology of non-fixed cells was examined by phase-contrast microscopy (Nikon Eclipse TE300). After differentiation, MDMis were cultured in RPMI supplemented with 10\% heat-inactivated FBS, 100 $\mathrm{U} / \mathrm{ml}$ penicillin $\mathrm{G}$ and $100 \mu \mathrm{g} / \mathrm{ml}$ streptomycin (Invitrogen, Burlington, ON, Canada).

Human embryonic kidney 293T (ATCC) and TZM-bl cells (NIH AIDS Research and Reference Reagent Program) were cultured in complete Dulbecco's modified Eagle's medium (DMEM) (that is, DMEM supplemented with $10 \%$ heat-inactivated FBS, $2 \mathrm{mM} \mathrm{L}$-glutamine, 100 $\mathrm{U} / \mathrm{ml}$ penicillin $\mathrm{G}$ and $100 \mu \mathrm{g} / \mathrm{ml}$ streptomycin).

\section{Immunofluorescence microscopy for microglia characterization}

Cells were seeded onto glass coverslips $(12 \mathrm{~mm}$ round, thickness \#1, Fisher Scientific, Nepean, ON, Canada) set in 24-well plates at $1 \times 10^{5}$ cells per well and treated with ACM for 14 days 2 days after peripheral blood monocytes were isolated and incubated in the presence of M-CSF and GM-CSF. Once monocytes were derived into MDMis, cells were first fixed with $4 \%(\mathrm{w} / \mathrm{v})$ room temperature paraformaldehyde-PBS for 20 minutes and next treated with a blocking solution (PBS supplemented with $1 \%$ bovine serum albumin (BSA), $0.2 \%$ Triton, $30 \%$ normal goat serum and $15 \%$ human serum) for 15 minutes followed by an incubation with a rabbit antiIBA1 antibody (diluted 1:500) in PBS containing 1\% BSA at room temperature for $1 \mathrm{~h}$. After washing, cells were incubated with goat anti-rabbit antibody conjugated with Alexa-555 (dilution 1:500) at room temperature for 30 minutes. After washing, coverslips were mounted on microscope slides using Fluoromount-G 
from Southern Biotech (Birmingham, Alabama, USA) and dried overnight in the dark. Cells were observed using a Nikon Eclipse TE300 microscope.

\section{Virus production}

Viruses were produced by the calcium phosphate coprecipitation method in 293T cells as described previously [49]. In brief, 293T cells were transiently transfected with pYU2 to produce fully infectious R5-tropic HIV-1 particles. In addition, 293T cells were cotransfected with pNL4-3Luc $E n v^{-} R^{+}$and either pJR-FLenv or pHCMV-G to obtain pseudotyped HIV-1-based reporter viruses. Virus preparations were normalized for virion content by using an in-house enzymatic assay specific for the major viral p24 protein. In this test, hybridomas 183H12-5C and 31-90-25 are used in combination to quantify p24 levels [50]. In addition, the infectivity of our virus stocks was assessed using TZM-bl indicator cells. This cell line is a genetically modified HeLa-derived cell line expressing large amounts of cell surface CD4, CCR5 and $\mathrm{C}-\mathrm{X}-\mathrm{C}$ chemokine receptor type 4 (CXCR4) [51]. These cells carry separate integrated copies of the luciferase and $\beta$-galactosidase genes under the control of the HIV-1 promoter and are highly susceptible to infection with different HIV-1 variants (both R5 and X4 tropic). Virus preparations that did not allow sufficient reporter gene activity were discarded.

\section{HIV-1 infection}

After cell differentiation, MDMis were washed extensively with PBS, plated at $1 \times 10^{5}$ cells per well were and incubated in a final volume of $400 \mu \mathrm{l}$ of RPMI supplemented with $10 \%$ heat-inactivated FBS, $100 \mathrm{U} / \mathrm{ml}$ penicillin $\mathrm{G}$ and $100 \mu \mathrm{g} / \mathrm{ml}$ streptomycin. Cells were treated with LTs either before (45 minutes) or after infection $(2,24$, or $48 \mathrm{~h})$ with luciferase-encoding pseudotyped viruses. As for infections using a fully replicative virus (that is, YU2), cells were treated with LTs both before and after infection where a fraction of the medium was removed $(50 \mu \mathrm{l})$ every 3 days and for a period lasting 9 days and kept frozen at $-20^{\circ} \mathrm{C}$. Virus infection was performed with a fixed amount of virus (that is, $10 \mathrm{ng}$ of p24 per $1 \times 10^{5}$ cells) for $2 \mathrm{~h}$ and cells were washed to remove excess virus. Virus production was estimated by measuring p24 levels in cell-free culture supernatants by ELISA. Luciferase activity was measured 7 days after infection using an MLX microtiter luminometer (Dynex Technologies, Chantilly, VA, USA) and is expressed as relative luciferase units (RLU). In some experiments, cell-free supernatants from MDMis either left untreated or treated with LTs and next infected with HIV-1 for 9 days were collected and virus infectivity was defined upon incubation with TZM-bl indicator cells.

\section{Flow cytometry analysis}

Before staining, cells were incubated for 15 minutes at $4{ }^{\circ} \mathrm{C}$ in PBS containing $0.1 \%$ sodium azide, $10 \%$ heatinactivated human fibrin-depleted plasma, 10\% normal goat serum (Jackson ImmunoResearch Laboratories, West Grove, PA, USA) and 10\% FBS to block non-specific binding sites and washed once with PBS containing $0.1 \%$ sodium azide and supplemented with $5 \%$ FBS. To monitor cell surface expression of CCR5, BLT1, BLT2, cysLT1 and cysLT2, MDMi samples, treated or not with LTs as indicated, were incubated with specific antibodies or with an appropriate isotype-matched irrelevant control antibody (for non-specific staining) for 30 minutes at $4^{\circ} \mathrm{C}$, or for 20 minutes at room temperature exceptionally for CCR5. Cells were then washed with PBS supplemented with $0.1 \%$ sodium azide and $5 \%$ FBS and fixed in a $2 \%$ paraformaldehyde solution before analysis by flow cytometry (Epics ELITE ESP; Coulter Electronics).

\section{Substance $\mathbf{P}$ detection}

Cell-free supernatants were obtained from monocytes cultured with or without ACM and blotted onto a 0.2 $\mu \mathrm{m}$ polyvinylidene fluoride (PVDF) membrane (Millipore, Billerica, MA, USA) using a vacuum slot blotter. The membrane was then blocked by incubation in PBS containing $5 \%$ dried milk and $0.2 \%$ Tween- 20 for $2 \mathrm{~h}$ and then probed with polyclonal rabbit antibody to substance $\mathrm{P}(1: 500)$ at $4^{\circ} \mathrm{C}$ overnight. Membranes were then washed four times for 15 minutes in PBS containing $0.2 \%$ Tween-20 and incubated for $1 \mathrm{~h}$ with HRP-conjugated goat-anti-rabbit IgG (1:20,000). After $2 \mathrm{~h}$ of washing in PBS containing $0.2 \%$ Tween-20, the reaction was visualized with the enhanced chemiluminescence system (ECL plus) as recommended by the manufacturer. Signal intensity on the film was quantified with densitometric analysis software (ImageJ).

\section{Real-time polymerase chain reaction (PCR)}

For detection and quantification of reverse transcripts and integrated viral DNA copies, MDMis $\left(1 \times 10^{6}\right)$ were pulsed for $2 \mathrm{~h}$ with a virus preparation (that is, YU2) previously treated with $20 \mathrm{U} / \mathrm{ml}$ grade II DNase-1 (Roche Applied Science, Qc, Canada). Cells were then either left untreated or treated for $8 \mathrm{~h}$ (transcripts) or $24 \mathrm{~h}$ (proviral DNA) with LTs $(10 \mathrm{ng} / \mathrm{ml})$. Genomic DNA was extracted using the DNeasy Blood and Tissue Kit from Qiagen (Toronto, ON, Canada). Quantification of HIV-1 reverse transcripts was achieved by real-time PCR in a $25 \mu \mathrm{l}$ reaction containing $25 \mathrm{ng}$ of DNA, TaqMan Universal PCR Master Mix (Applied Biosystems, Foster City, CA, USA), $1 \mu \mathrm{M}$ each of HIV-1-specific sense M667 and antisense M661 primers and $0.3 \mu \mathrm{M}$ of the TaqMan probe HIV-5'-carboxyfluorescein (Biosearch 
Technologies, Novato, CA, USA) [52]. For monitoring integrated viral DNA copies, DNA was subjected to a combined Alu-HIV-1 PCR and real-time PCR as described previously [53]. Briefly, genomic DNA (100 ng) was first amplified with an $A l u$-sequence-specific sense primer and HIV-1-specific antisense primer (that is, M661) [54]. Next, $5 \mu \mathrm{l}$ of 20 -fold diluted PCR products were subjected to a real-time PCR assay in a $25 \mu \mathrm{l}$ reaction containing TaqMan Universal PCR Master Mix, $2 \mu \mathrm{M}$ of the HIV-1-specific sense primer M667, $2 \mu \mathrm{M}$ of the HIV-1-specific antisense primer AA55 and 0.3 $\mu \mathrm{M}$ of the TaqMan probe HIV-5'-carboxyfluorescein (Biosearch Technologies) [53]. We used a standard curve made of known amounts of input viral DNA (that is, pNL4-3 ranging from 469 to 30,000 copies). All HIV1 standards contained $1 \mathrm{ng}$ of DNA from uninfected cells as carrier. To quantify 2LTR circles, $125 \mathrm{ng}$ of DNA per $5 \mu \mathrm{l}$ was subjected to a real-time PCR reaction containing TaqMan Universal PCR Mix, $2 \mu \mathrm{M}$ of the HIV-1 2LTR-specific primers (sense: CCCTCAGACCCTTTTAGTCAGTG; antisense: TGGTGTGTAGTT CTGCCAATCA) and $0.3 \mu \mathrm{M}$ of the TaqMan probe 2LTR-FAM (GGA TCT ACC ACA CAC AAG GCT TCC) [53]. To ensure quantification precision, all HIV-1 real-time PCR amplified samples were normalized using the $\beta$-globin housekeeping gene. From every diluted DNA samples, $\beta$-globin was quantified using $1 \mu \mathrm{M}$ of sense (TGGTCTATTTTCCCACCCT) and antisense (TGGCAAAGGTGCCCTTGA) specific primers and 0.3 $\mu \mathrm{M}$ of the TaqMan probe $5^{\prime}-\beta$-globin-CAL Fluor 560 (TCTGTCCACTCCTGATGCTG-BHQ-1 3') (Biosearch Technologies). Equal parts of every sample were pooled and successive twofold dilutions were used as a relative standard curve for $\beta$-globin quantification. The cycling conditions used for the Applied Biosystems 7500 sequence detection system included a hot start $\left(50^{\circ} \mathrm{C}\right.$ for 2 minutes and $95^{\circ} \mathrm{C}$ for 10 minutes), followed by 40 cycles of denaturation $\left(95^{\circ} \mathrm{C}\right.$ for 1 minute) and extension $\left(63^{\circ} \mathrm{C}\right.$ for 1 minute) with end point acquisition.

\section{Statistical analysis}

All experiments were repeated at least three times and each figure combines the results obtained with all the different donors unless otherwise specified. The statistical significance of the difference between groups was determined using the Student t test. Calculations were made with Prism version 3.03 (GraphPad Software, Inc. La Jolla, CA, USA). The $P$ values $<0.05$ were considered statistically significant.

\section{Results}

Because of the limited access to primary microglial cells isolated from human brain specimens, which renders experimental approaches that require large quantities of cells difficult to achieve, we turned to a previously described experimental model system to study the possible modulatory role of LTs in HIV-1 infection in microglia. This unique cellular model is capable of supporting productive infection with HIV-1 [55]. Furthermore, this in vitro model mimics infiltrating microglia [56,57], one of the cell types mostly responsible for disseminating HIV-1 in the CNS.

\section{Validation of the cellular model}

Microglial-like cells are characterized by a typical quiescent microglia morphology consisting in long branching processes and a small cellular body. These cells also express IBA1, which is an intracellular molecule marker known to be abundantly expressed in microglia [58]. To validate our cellular model, we first examined the morphology of the cells, as well as their IBA1 expression level. As expected, ACM-treated monocytes display typical microglia morphology following differentiation (Figure 1A) and express much higher levels of IBA1 than non-ACM-treated cells (used as control cells) (Figure 1B). Substance $P$, the most abundant neurokinin in the CNS, is secreted in significantly higher amounts by microglia than monocyte-derived macrophages [59]. Indeed, our MDMi preparations were found to produce considerably more substance $\mathrm{P}$ than non-ACM treated monocytes (Figure 1C). Furthermore, MDMis were found to be permissive to productive infection with the brain-derived R5-using HIV-1 isolate YU2, but produced less progeny virus than non-ACM-treated monocytes (Figure 1D), which is in line with previous published observations [55]. In addition, MDMis were found to be refractory to infection with a prototypic X4-using HIV-1 variant (that is, NL4-3) (data not shown). Altogether, these data show that our cellular model displays the hallmarks of microglial-like cells.

We also analyzed the surface expression of $\mathrm{LTB}_{4}$ (that is, BLT1 and BLT2) and cysLT receptors (that is, cysLT1 and cysLT2) on MDMis. In our study, neither BLT2 nor cysLT1 were detected on MDMis by flow cytometry (data not shown). However, BLT1 and CysLT2 were found to be expressed on these cells, albeit at a moderate level, with mean fluorescence intensities of 2,200 and 993, respectively (Figure 1E).

\section{LTs decrease HIV-1 replication in MDMis}

We next evaluated if LTs could modulate HIV-1 replication in MDMis. To do so, MDMis were initially treated, or not, with either $\mathrm{LTB}_{4}$ or $\mathrm{LTC}_{4}$ and then infected with the fully replicative R5-tropic strain YU2. Viral production was monitored for a period of 9 days. It is noteworthy that LTs were replenished during the experiment (that is, at days 3 and 6) because they are known to be very unstable. To make sure that the effect 


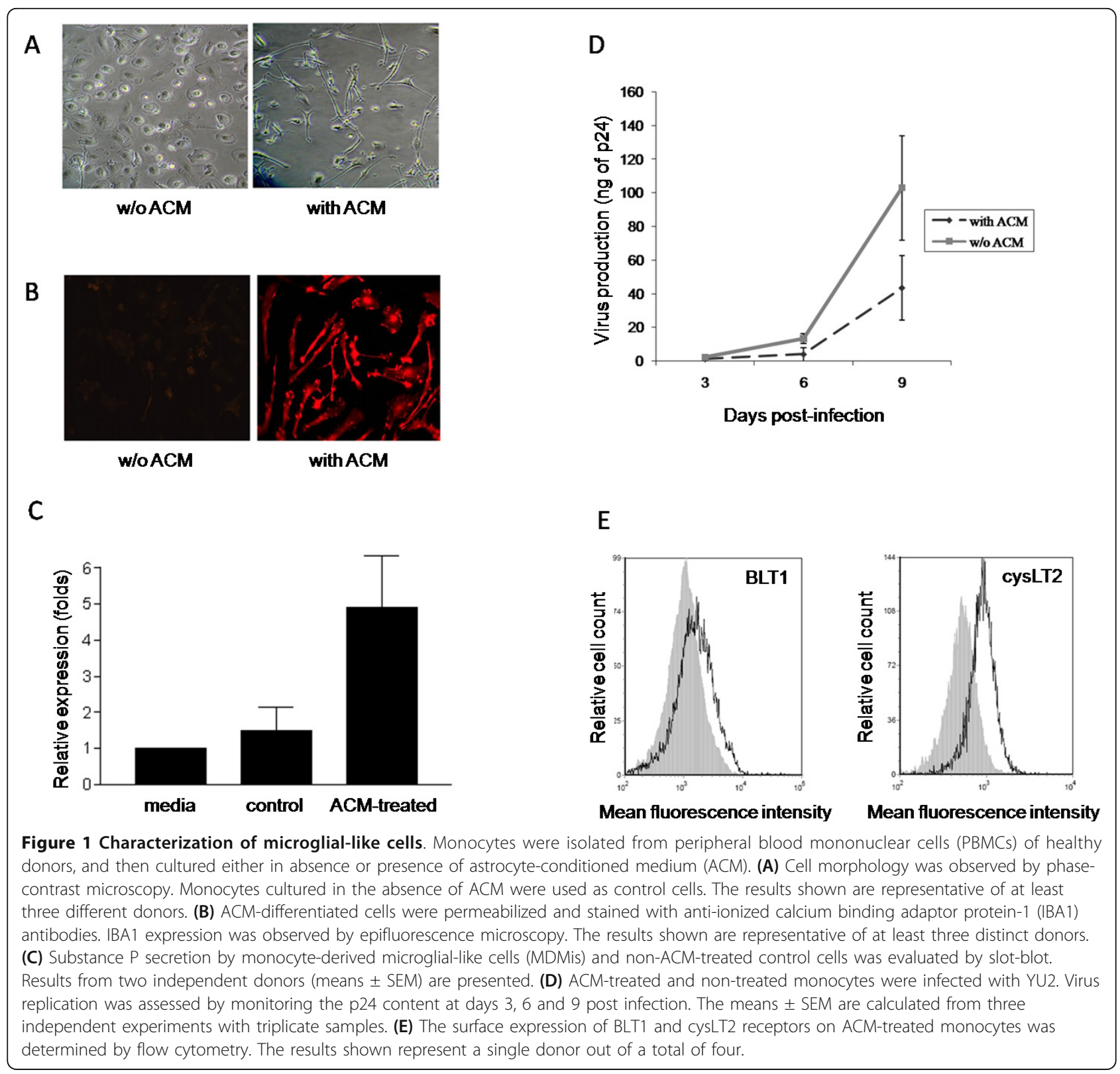

of LTs on HIV-1 infection was receptor specific, we used as controls the two less active metabolites 20-carboxy-LTB (called $20-\mathrm{COOH} \mathrm{LTB}_{4}$ ) and $N$-acetyl $\mathrm{LTE}_{4}$ (called $\mathrm{N}$-Ac $\mathrm{LTE}_{4}$ ). For example, the biological activity of 20 -carboxy- $\mathrm{LTB}_{4}$ is only $2.6 \%$ of that of $\mathrm{LTB}_{4}$ in causing human leukocyte degranulation [60], whereas $N$-Ac $\mathrm{LTE}_{4}$ is 100 times less potent than $\mathrm{LTC}_{4}$ as a vasoconstricting agent [61]. Treatment of MDMis with $\mathrm{LTB}_{4}$ and $\mathrm{LTC}_{4}$ causes a diminution in HIV-1 infection, as assessed by 24 values, to a greater extent than when using the less potent catabolites (Figure 2A, B). To validate whether the LT-mediated decrease in p24 levels correlates with a diminution of virus infectivity, supernatants were transferred onto TZM-bl indicator cells.
The relative infectivity was assessed by comparing the luciferase activity generated by supernatants from YU2infected (that is, 9 days post infection) MDMis either left untreated or treated with LTs or the less active analogs. Data from Figure $2 \mathrm{C}$ revealed that production of infectious virus is reduced in a more significant manner by LTs (that is, $61 \%$ reduction with $\mathrm{LTB}_{4}$ and $74 \%$ diminution with $\mathrm{LTC}_{4}$ ) compared to MDMis treated

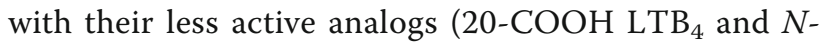
Ac $\mathrm{LTE}_{4}$, respectively), which is in agreement with p24 values. The colorimetric MTS assay revealed no toxicity mediated by LTs in MDMis at the highest concentration tested (that is, $100 \mathrm{ng} / \mathrm{ml}$ ) for a period of 9 days (data not shown). 


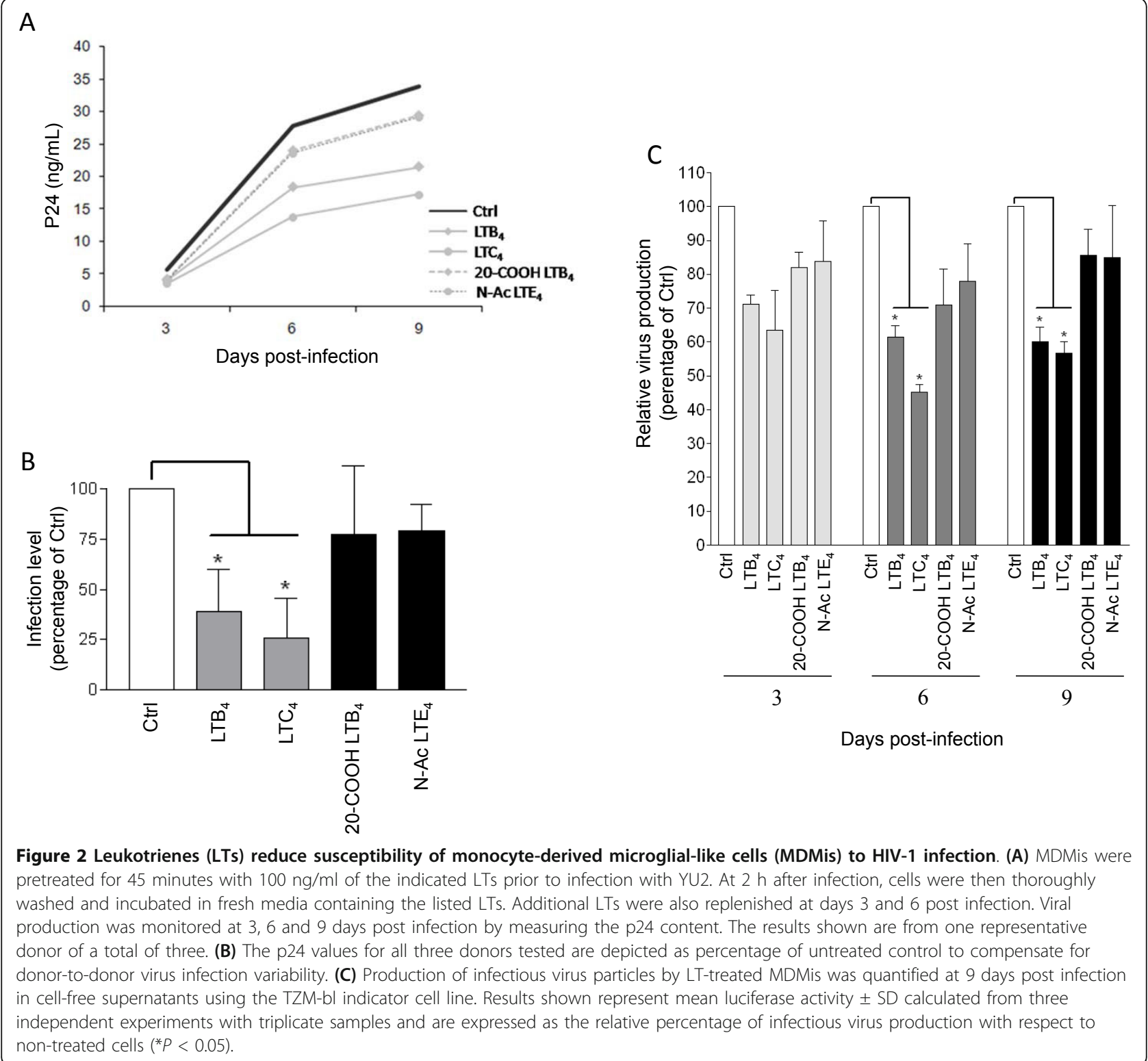

\section{$\mathrm{LTB}_{4}$ and $\mathrm{LTC}_{4}$ inhibit early steps in HIV-1 replication in MDMis}

We next sought to determine which step(s) of the HIV1 life cycle LTs affected in MDMis. This goal was achieved by performing a timecourse experiment with luciferase-encoding single-cycle reporter viruses. Moreover, to define whether LTs can alter the process of virus entry, MDMis were inoculated with both R5 (that is, JR-FL envelope) and VSV-G pseudotyped reporter viruses. This is based on the idea that VSV-G pseudotypes enter cells by a $\mathrm{pH}$-dependent endocytosis process and independently of the natural $\mathrm{pH}$-independent pathway that relies on HIV-1 receptor and coreceptors. As shown in Figure 3, treatment of MDMis with LTs prior to virus infection reduced infection with JR-FL pseudotypes in a dose-dependent manner (A), whereas infection with reporter viruses pseudotyped with VSV-G was left unaffected (B), therefore suggesting that the initial steps in the replicative cycle of HIV-1 in MDMis are negatively affected by LTs. However, infection by both JR-FL and VSV-G pseudotypes was reduced when LTs were added to MDMis at $2 \mathrm{~h}$ or $24 \mathrm{~h}$ post infection (with the strongest effect seen at $2 \mathrm{~h}$ post infection), thus suggesting that a post-fusion step is also affected by LT treatment. The late infection stages (that is, after viral integration) are not touched by LTs since no significant modulatory effect was seen when cells were treated at a later time point (that is, $48 \mathrm{~h}$ post infection). Although a greater inhibition was observed when using a final concentration of $100 \mathrm{ng} / \mathrm{ml}$ of LTs, the more 


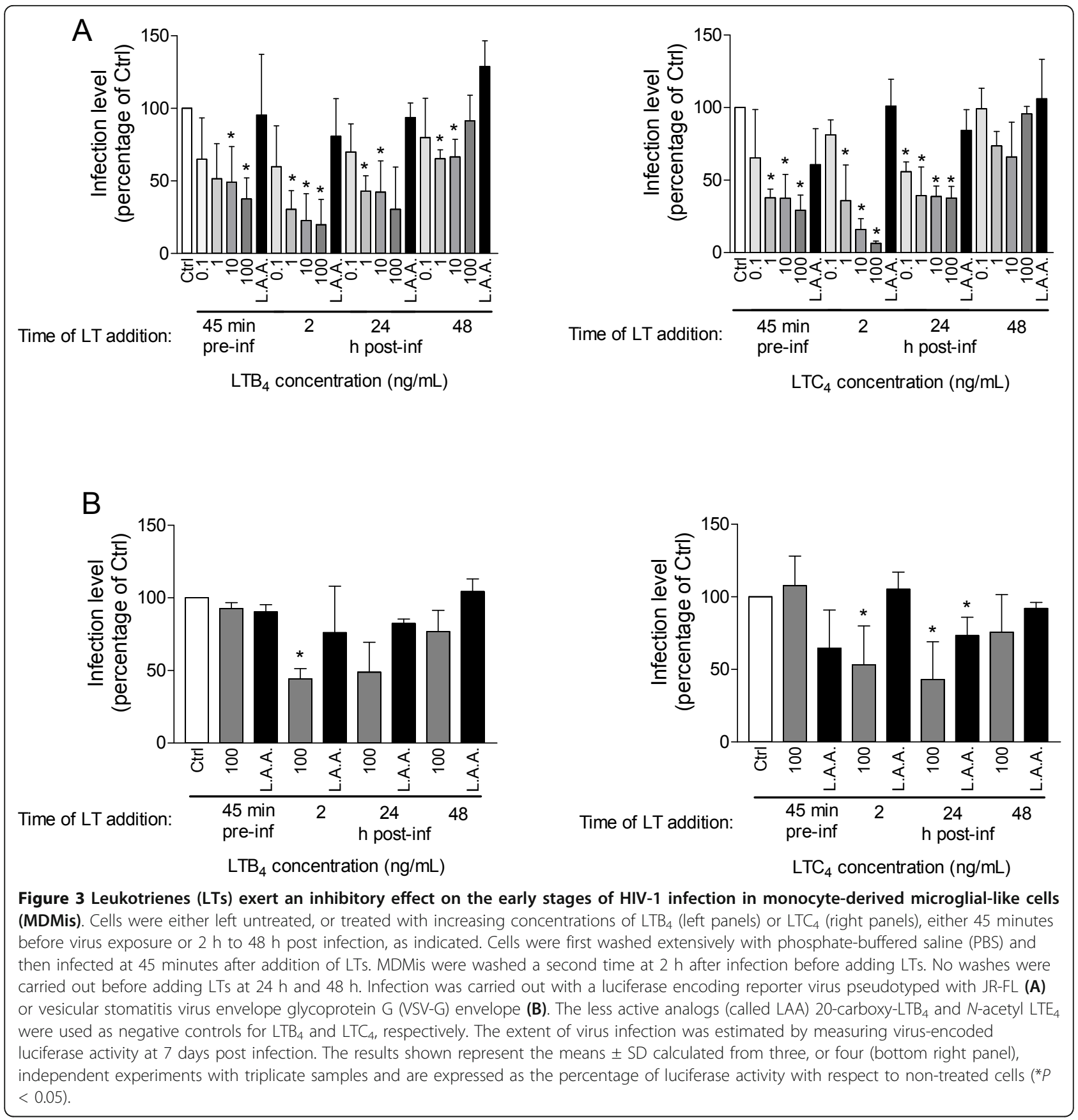

physiological concentration of $10 \mathrm{ng} / \mathrm{ml}$ was used in subsequent experiments.

To further validate that $\mathrm{LTB}_{4}$ and $\mathrm{LTC}_{4}$ must engage their respective receptors in order to modulate the early steps of HIV-1 replication, MDMis were treated with potent $\mathrm{LT}$ receptor antagonists prior to $\mathrm{LT}$ treatment and infection with JR-FL pseudotypes. To this end, LY293111 was used to block BLT1 while Bay-u9773 was used to block cysLT1/2. Results show that the $\mathrm{LTB}_{4} /$ $\mathrm{LTC}_{4}$-induced inhibition of viral production in MDMis is totally abolished by LY293111 or Bay-u9773, respectively (Figure 4).

\section{$\mathrm{LTB}_{4}$ and $\mathrm{LTC}_{4}$ downregulate surface expression of CCR5 on MDMis}

Because pretreatment of MDMis with LTs affects infection by JR-FL but not VSV-G pseudotypes, we hypothesized that the $\mathrm{pH}$-independent fusion step of the virus life cycle is likely inhibited by LTs. We investigated whether this could occur via a decrease in the 


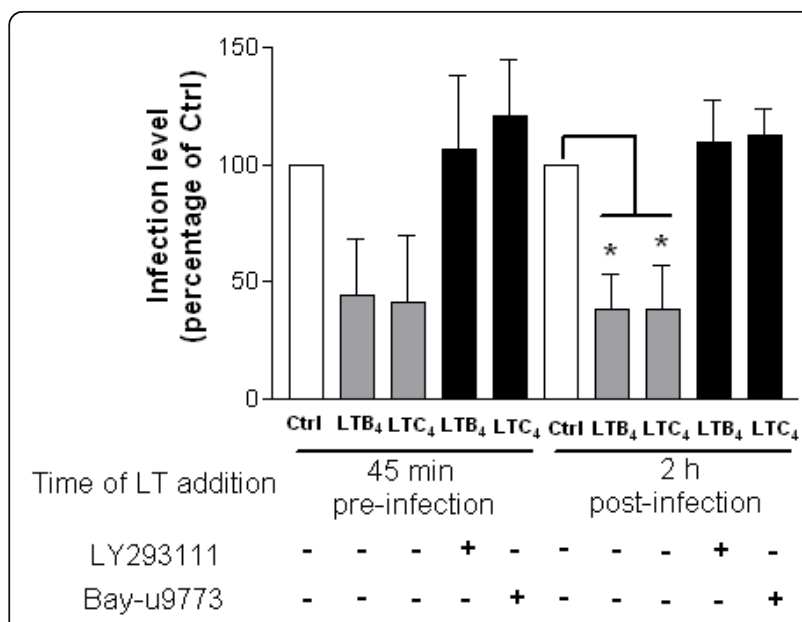

Figure 4 Leukotriene (LT) receptor antagonists block the modulatory effect of $\mathrm{LTB}_{4}$ and $\mathrm{LTC}_{4}$ on HIV-1 replication in monocyte-derived microglial-like cells (MDMis). Cells were either left untreated (Ctrl) or treated with the listed LT receptor antagonists (that is, LY293111 or Bay-u9773) for 45 minutes before being thoroughly washed. MDMis were then either exposed to LTs 45 minutes before or $2 \mathrm{~h}$ following HIV-1 infection, after which cells were thoroughly washed. Virus infection was carried out using JR-FL pseudotyped viruses. The extent of virus infection was estimated by measuring virus-encoded luciferase activity at 7 days post infection. The results shown represent the means \pm SD calculated from three independent experiments with triplicate samples and are expressed as the percentage of luciferase activity with respect to non-treated cells $(* P<0.05)$.

expression of the HIV-1 coreceptor CCR5. Results obtained by flow cytometry show that incubation of MDMis in the presence of $\mathrm{LTB}_{4}$ or $\mathrm{LTC}_{4}$ for a $24-\mathrm{h}$ period caused a diminution in the percentage of MDMis expressing CCR5 at the cell surface (Figure 5). Meanwhile, CCR 5 expression remained unaffected after a 45minute incubation period (data not shown), which points to an indirect effect on CCR5, rather than a direct receptor heterologous desensitization. These data suggest that LTs likely inhibit productive HIV-1 infection in MDMis partly via a modulation of CCR5 surface expression.

\section{LTs reduce virus integration}

To gain insights on the nature of HIV-1 post-fusion events modulated by LTs, we then analyzed the reverse transcription and integration processes. Completed reverse transcripts and proviral DNA were quantified by real-time PCR in MDMis treated with LTs. Here, in order to distinguish the post-entry events from the consequences on the $\mathrm{pH}$-independent viral entry at the plasma membrane, cells were treated with LTs at $2 \mathrm{~h}$ post infection. As shown in Figure 6, $\mathrm{LTB}_{4}$ and $\mathrm{LTC}_{4}$ had no significant impact on the amount of completed HIV-1 reverse transcription products, whereas both LTs induced a $50 \%$ reduction of integrated proviral DNA in MDMis.

The effect of LTs on HIV-1 infection is reliant on PKC It is known that treatment of cells with LTs is often associated with PKC activation. Besides, Warrilow and coworkers have shown that some PKC modulatory compounds inhibit HIV-1 infection in PBMCs [62]. We therefore evaluated the involvement of PKC in the LTmediated inhibitory effect on HIV-1 replication in MDMis. To do so, MDMis were treated, or not, with the large-spectrum PKC inhibitor Ro318220, prior to their exposure to luciferase-encoding HIV-1 particles. LTs were added on cells either 45 minutes before or $2 \mathrm{~h}$ after infection, and luciferase activity was then measured 7 days post infection. Results illustrated in Figure 7A demonstrate that the LT-induced modulation of HIV-1 infection in MDMis is abolished upon treatment with the PKC inhibitor, indicating that a PKC-mediated signal transduction pathway is involved in that phenomenon. Furthermore, the fact that the effect is observed whether LTs are added before or after infection indicates that PKC is involved in both early and post-fusion events of HIV-1 infection. To better define the involvement of PKC in the LT-modulated inhibitory effect on HIV-1 post-fusion events, we quantified both integration events and the formation of 2LTR circles in MDMis treated or not with the large spectrum PKC inhibitor Ro318220 prior to their exposure to LTs. It is important to note that the number of 2LTR circles serves as a quantitative measurement for nuclear import. For this set of experiments, VSV-G-pseudotyped viral particles were used in order to achieve a high infection efficiency that is necessary to detect the relatively rare 2LTR circle intermediates. As illustrated in Figure 7B, the reduction in intregrated proviral DNA in MDMis treated with the studied LTs is totally abolished following Ro318220 treatment. Moreover, a detectable reduction in the level of 2LTR circles was also observed in LT-treated MDMis, indicating a blockage at or before the nuclear import steps of the viral replication cycle (Figure 7C). However, Ro318220 failed to abolish this effect of LTs on 2LTR in MDMis, which points to another PKC-independent pathway that might also inhibit HIV-1 production in MDMis.

\section{Discussion}

There is a paucity of data regarding the impact of potent eicosanoid lipid mediators on HIV-1 replication. Eicosanoids include four distinct families, that is, prostaglandins, prostacyclins, thromboxanes and LTs. Various studies have shown that prostaglandins can induce cellular resistance to HIV-1 [63-66]. As for LTs, only recently have we considered them as antimicrobial or 


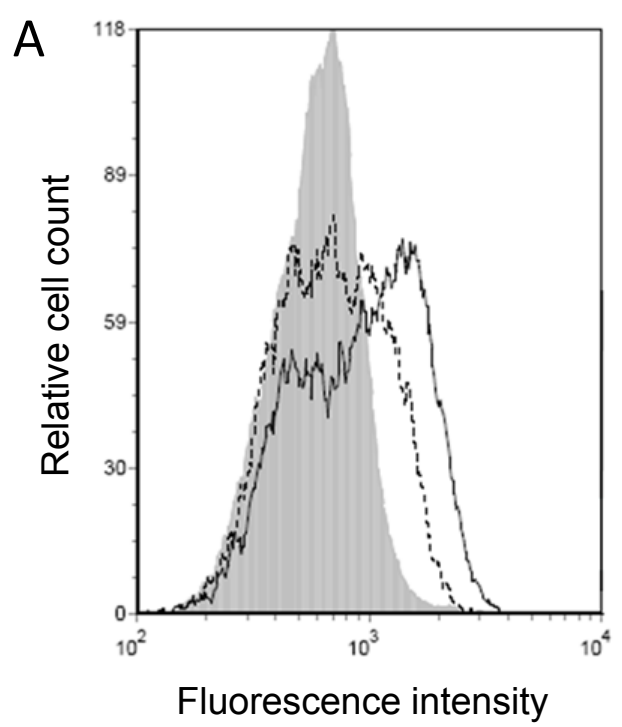

C

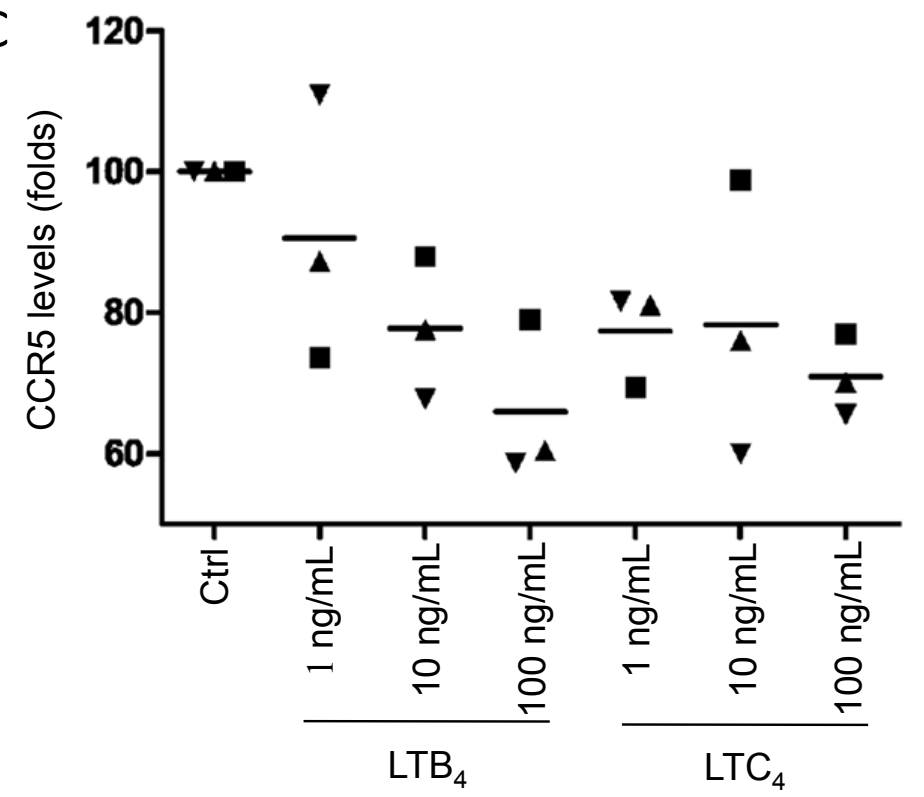

Figure 5 Leukotriene (LT) $\mathrm{B}_{4}$ and $\mathrm{LTC}_{4}$ induce a downmodulation of C-C chemokine receptor type 5 (CCR5) surface expression on monocyte-derived microglial-like cells (MDMis). Cells were either left untreated (continuous lines) or treated with $10 \mathrm{ng} / \mathrm{ml}$ of $(\mathbf{A}) \mathrm{LTB} \mathrm{B}_{4}$ or (B) $\mathrm{LTC}_{4}$ (dotted lines) for $24 \mathrm{~h}$ before labeling with a phycoerythrin (PE)-conjugated anti-CCR5 antibody or PE-conjugated irrelevant control antibody (gray areas). Expression levels of CCR5 were determined by flow cytometry. Results shown are from one donor representative of three. (C) MDMis were either left untreated or treated with increasing concentrations of LTs for $24 \mathrm{~h}$ before labeling with a PE-conjugated anti-CCR5 antibody. To compensate for donor-to-donor variations, the results shown represent the mean percentage of CCR5 positive cells \pm SD calculated from three independent experiments and are expressed as percentages of control $(C \mathrm{trl})\left({ }^{*} P<0.05\right)$.

anti-HIV-1 mediators $[44,45,59,67-70]$. In the CNS in particular, the interaction between LTs produced by immune cells and HIV-1 infection is poorly understood. We therefore focused our studies on the effect of LTs on HIV-1 infection in microglial cells. We chose to conduct our experiments in MDMis since this novel in vitro model mimics infiltrating microglia that are

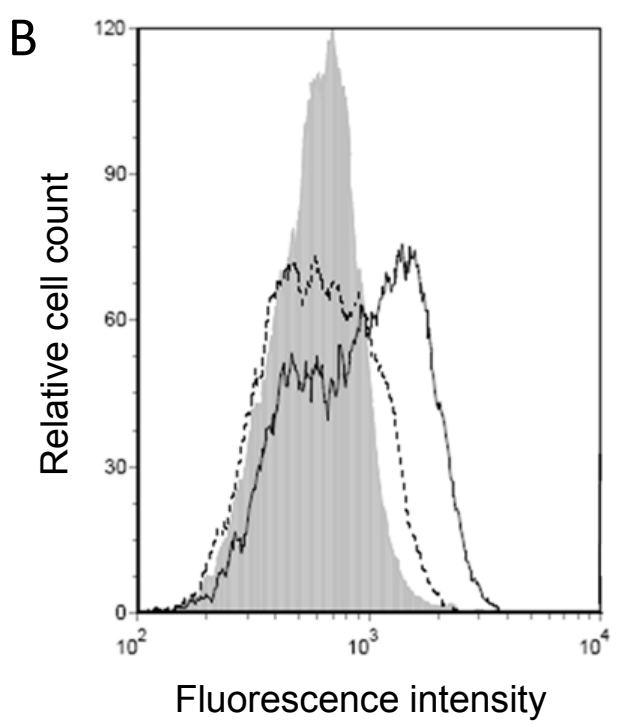

- Donor 1

A Donor 2

$\checkmark$ Donor 3 subjected to productive HIV-1 infection under in vivo situations.

To the best of our knowledge, other than one recent publication [71] no further studies on MDMi cells have been published following their initial characterization by Leone and colleagues in 2006 [55]. For this reason, we first validated our MDMis by verifying their 


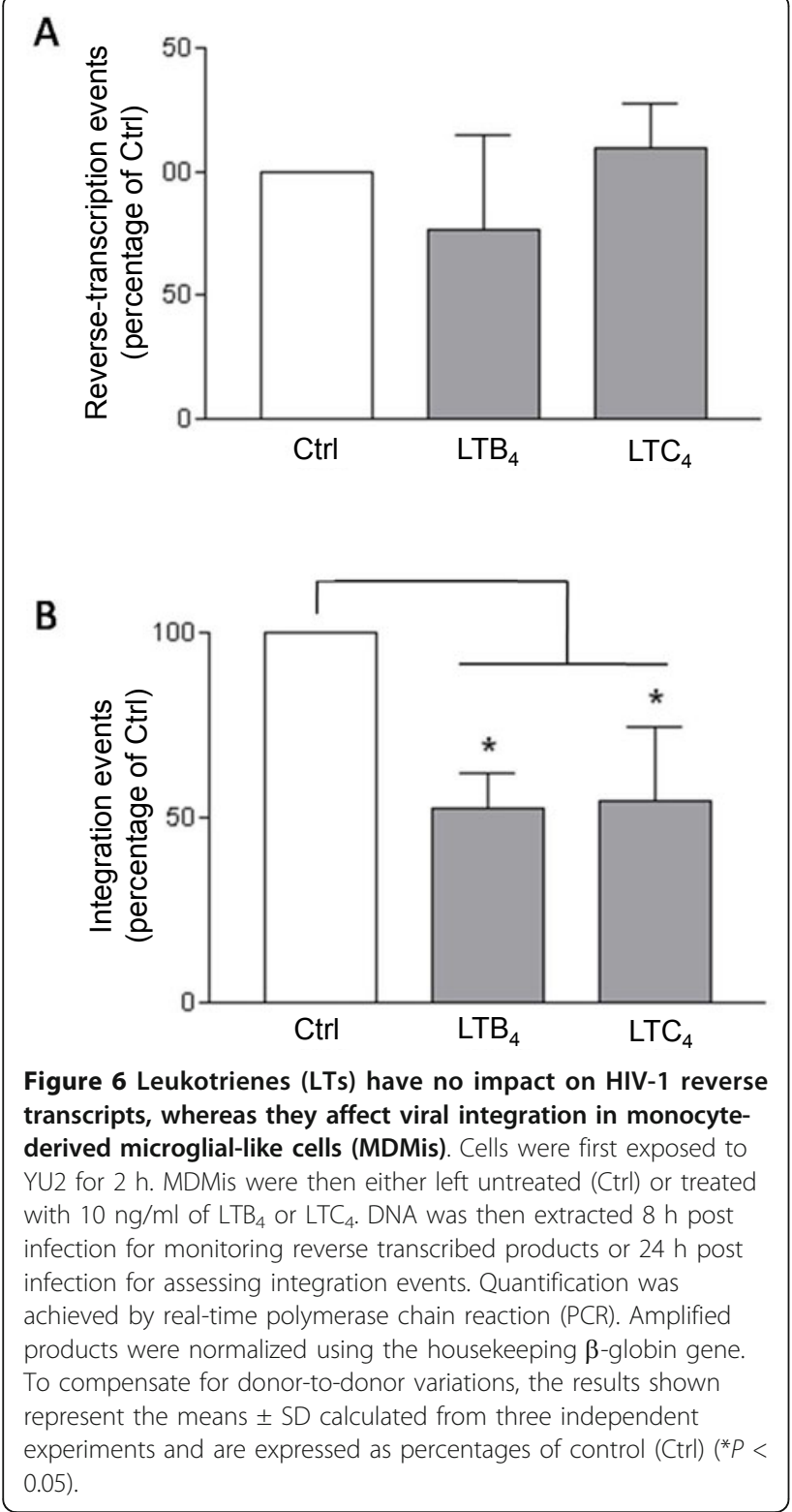

morphology, IBA1 expression, substance P production and susceptibility to HIV-1 infection. We also verified the presence of $\mathrm{LTB}_{4}$ and $\mathrm{LTC}_{4}$ receptors on these cells. We were thus able to test this novel cellular model, which allowed us to overcome the difficulty of obtaining primary human microglial cells in sufficient quantities.

We determined that both $\mathrm{LTB}_{4}$ and $\mathrm{LTC}_{4}$ decrease productive HIV-1 infection of MDMis. More precisely, LTs seem to negatively modulate the earliest as well as post-fusion events. However, we were not able to observe any effects on late stages of infection (48 h post infection). The concentrations used in the current study seem higher than the LT concentrations found in the CSF in inflammatory conditions, which can vary between 116 and $348 \mathrm{pg} / \mathrm{ml}$ [32,37]. However, levels of LTs in CSF are probably an undervaluation of the amount produced in brain tissue. Indeed, because LTs can be secreted locally by glial cells, concentrations similar or higher to those used in our work are likely reached in the microenvironment surrounding brain microglial cells based on the notion that pg of LTs are measured per $\mathrm{g}$ of brain tissue.

We examined whether the HIV-1 coreceptor CCR5 was affected by the studied LTs. Since we did not observe any CCR5 modulation when MDMis were preexposed to LTs for 45 minutes, LTs likely do not cause CCR5 internalization by means of heterologous desensitization, which is a mechanism of rapid internalization of unstimulated $\mathrm{G}$ protein-coupled receptors that occurs despite the continued presence of a ligand. However, MDMis exposed to LTs for a longer period (24 h) showed a dose-dependent decrease in CCR5 surface expression. LT-treated MDMis might produce different $\beta$-chemokines (for example, macrophage inflammatory protein (MIP)- $1 \alpha$, MIP-1 $\beta$ and chemokine (C-C motif) ligand 5 (CCL5, also known as RANTES)), which may be responsible for the delayed CCR5 downmodulation by means of homologous desensitization partly responsible for the negative effect of LTs on the production of virion progeny. Further studies will be needed to pinpoint the exact mechanisms by which CCR5 is modulated by LTs. Besides, it is possible that MDMis exposed to LTs show attenuated levels of other surface molecules known to play a role in HIV-1 infection in the CNS, such as CCR3 or galactocerebroside (or galactosylceramide). Although controversial, it has been shown that $\mathrm{LTB}_{4}$ receptor could act as a coreceptor for HIV-1 in CD4-positive cells [72,73]. If true, competition for LT receptors might be one explanation for how LTs attenuate HIV-1 replication in MDMis.

The early stages of HIV-1 replication include all steps from binding at the cell surface to integration into the nucleus [74]. At the post-entry level, these early events consist of viral decapsidation, reverse transcription, nuclear import and integration. Interestingly, the strongest inhibition with respect to HIV-1 replication in MDMis was measured when target cells were exposed to LTs $2 \mathrm{~h}$ post infection, which is after virus entry. Thus, early postentry events may also be targeted. We indeed detected lower amounts of integrated viral DNA in MDMis exposed to LTs $2 \mathrm{~h}$ following their infection, while the reverse-transcribed products remained unaffected. These data suggest that post-entry inhibition of HIV-1 infection by LTs in MDMis occurs between the reverse transcription and integration steps. Nuclear import of the HIV-1 genome is mediated by a central HIV-1 DNA flap that is formed at the end of reverse transcription [75]. This three-stranded DNA structure is necessary for the 


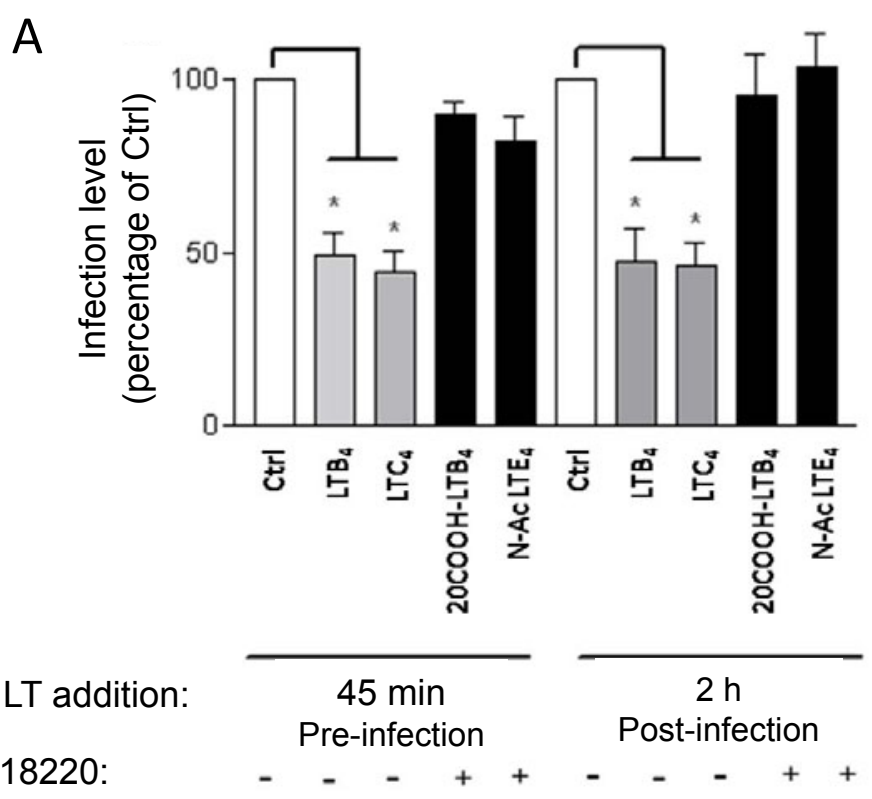

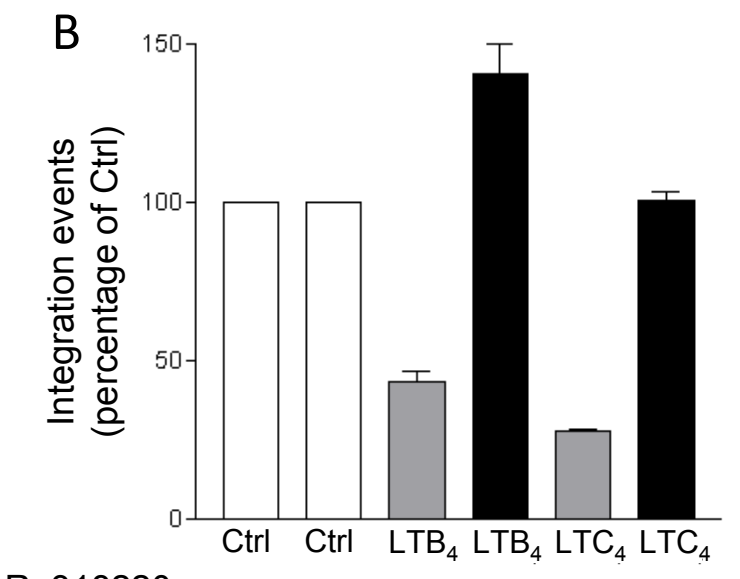

Ro318220:
Time of LT addition:

Ro318220:

Figure 7 Leukotrienes (LTs) reduce HIV-1 infection of monocyte-derived microglial-like cells (MDMis) in a protein kinase C (PKC)dependent manner. (A) MDMis were first either left untreated or treated with the large-spectrum PKC inhibitor Ro318220 (1 $\mu$ M) for 30 minutes. LTs $(10 \mathrm{ng} / \mathrm{ml})$ were then added to cells either for 45 minutes before infection or after $2 \mathrm{~h}$ of incubation with JR-FL pseudotypes. Luciferase activity was measured 7 days post infection. (B, C) MDMis were first infected with vesicular stomatitis virus envelope glycoprotein $G$ (VSV-G) pseudotypes for a $2 \mathrm{~h}$ period, cells were then treated with Ro318220 for 45 minutes, washed, and treated with LTs (100 ng/ml). Total DNA was extracted from cells in order to quantify HIV-1 integration events (panel B) and nuclear 2LTR circles (C) by real-time polymerase chain reaction (PCR). The results shown are expressed as percentages of control (that is, untreated cells) and calculated from five (A) or two (B, C) independent experiments in triplicate samples $\left({ }^{*} P<0.05\right)$.

uncoating process that characterizes the maturation of reverse transcribed complexes into preintegration complexes [76]. Little is known about the regulation of such events by host cell factors. It is possible that signals transduced from LT receptors interfere with the formation of the DNA flap or the uncoating process. Further research will be needed to investigate these possibilities.
Interestingly, previous studies have shown that PKC modulatory compounds can affect the early events of HIV-1 infection in PBMCs [62]. Incubation of MDMis with a large spectrum PKC inhibitor abolished the effect of LTs on HIV-1 infection both at the early and postfusion levels. PKC thus act as second messengers responsible for the LT-mediated reduction in HIV-1 
infection. There are 12 PKC isozymes distributed either in the conventional (require calcium, diacylglycerol and phospholipids for activation), novel (require diacylglycerol for activation) or atypical (require neither calcium nor diacylglycerol for activation) subfamilies. Although it is not yet known which PKC isozymes are expressed in MDMis, LT stimulation could activate any of these PKC in this cellular model. Additional studies will be needed to identify which PKC isozymes and what downstream signals are implicated in the inhibition of HIV-1 in MDMis by LTs. To determine more precisely which post-fusion step is inhibited by LTs in MDMis via PKC, we measured integrated viral DNA and nuclear 2LTR circles. We found that integrated proviral DNA is diminished by LTs in a PKC-dependent manner while 2LTR levels are decreased independently of the PKC signaling pathway in MDMis. Consequently, it can be proposed that LTs block the integration process after formation of the 2LTR circles in the nucleus by a mechanism that is partly mediated by $\mathrm{PKC}$, but a reduction of the nuclear import via a PKC-independent pathway cannot be excluded. Nuclear import of the HIV-1 preintegration complex depends on members of the cell nuclear transport machinery such as karyopherin $\beta$ transportin-3 (TNPO3) and nucleoporin 153 (NUP153) [77-79]. Interestingly, this nuclear transport machinery is inhibited by phosphorylation via mitogen-activated protein kinase kinase (MEK) and phosphatidylinositol 3kinase signaling [80]. It is possible that such signal transduction pathways are induced by LT treatment, causing nucleoporin phosphorylation and inhibition of nuclear import. Additional studies are needed to solve this issue.

\section{Conclusions}

In summary, the goal of this study was to analyze the possible involvement of LTs in the control of HIV-1 infection in microglia. The results of this study indicate that $\mathrm{LTB}_{4}$ and $\mathrm{LTC}_{4}$ inhibit some early events of the HIV-1 replication cycle in MDMis and that this effect relies on PKC. Now, if confirmed in vivo, what physiological relevance would be presented by the observed attenuation of HIV-1 infection by LTs? In the postHAART era, individuals still show mild symptoms of neuroinflammation associated to HIV-1 infection. LTs, among other proinflammatory molecules, are often found in the CSF of patients who are infected with HIV-1. Because of the high selectivity and low permeability of the BBB, the CNS is under weak immunological surveillance. However, viral load in the CNS is rarely much higher than in peripheral blood. Neuroinflammation, accompanied by production of LTs, may play a protective role against viral attack such as HIV-1. Since microglia are largely responsible for productive HIV-1 infection in the CNS, the data presented here provide an insight into how LTs may be one factor that help control viral load in the CNS compartment. Although some previous studies reported no adverse side effects associated with intravenous injections of $\mathrm{LTB}_{4}$ to humans or monkeys [44,45], additional research will be needed to determine if LTs can be used as a treatment or prophylaxis for HIV-1 infection. Thus, experimental studies using in vivo models will be needed to clarify the exact role of these proinflammatory lipid mediators in the modulation of viral load in the CNS.

\section{Acknowledgements}

The authors appreciate the excellent technical contribution of Caroline Côté and Marc-André Roy. We express our gratitude to Sylvie Méthot for her critical and constructive comments for the writing of this paper. This study was performed by JB in partial fulfillment of a PhD degree in the Microbiology and Immunology Program, Faculty of Medicine, Laval University. This study was supported by an Emerging Team Grant in HIV Pathogenesis to MJT from the Canadian Institutes of Health Research (CIHR) (grant \#HET-85519). MJT holds the Canada Research Chair in Human Immuno-Retrovirology (Tier 1 level).

\section{Authors' contributions}

$J B$ carried out most experiments described in the manuscript and drafted the manuscript. CB participated in the design and coordination of the study and helped to draft the manuscript. DB developed the cell culture system described in this work. MJT participated in the design and coordination of the study and helped to draft the manuscript. All authors read and approved the final manuscript.

\section{Competing interests}

The authors declare that they have no competing interests.

Received: 23 August 2011 Accepted: 16 March 2012

Published: 16 March 2012

\section{References}

1. Antinori A, Arendt G, Becker JT, Brew BJ, Byrd DA, Cherner M, Clifford DB, Cinque P, Epstein LG, Goodkin K, Gisslen M, Grant I, Heaton RK, Joseph J, Marder K, Marra CM, McArthur JC, Nunn M, Price RW, Pulliam L, Robertson KR, Sacktor N, Valcour V, Wojna VE: Updated research nosology for HIV-associated neurocognitive disorders. Neurology 2007, 69:1789-1799.

2. Ghafouri M, Amini S, Khalili K, Sawaya BE: HIV-1 associated dementia: symptoms and causes. Retrovirology 2006, 3:28.

3. Canestri A, Lescure FX, Jaureguiberry $S$, Moulignier A, Amiel C, Marcelin AG, Peytavin G, Tubiana R, Pialoux G, Katlama C: Discordance between cerebral spinal fluid and plasma HIV replication in patients with neurological symptoms who are receiving suppressive antiretroviral therapy. Clin Infect Dis 2010, 50:773-778.

4. Christo PP, Greco DB, Aleixo AW, Livramento JA: HIV-1 RNA levels in cerebrospinal fluid and plasma and their correlation with opportunistic neurological diseases in a Brazilian AIDS reference hospital. Arq Neuropsiquiatr 2005, 63:907-913.

5. De Luca A, Ciancio BC, Larussa D, Murri R, Cingolani A, Rizzo MG, Giancola ML, Ammassari A, Ortona L: Correlates of independent HIV-1 replication in the CNS and of its control by antiretrovirals. Neurology 2002, 59:342-347.

6. Schnell G, Spudich S, Harrington P, Price RW, Swanstrom R: Compartmentalized human immunodeficiency virus type 1 originates from long-lived cells in some subjects with HIV-1-associated dementia. PLoS Pathog 2009, 5:e1000395.

7. Peters PJ, Bhattacharya J, Hibbitts S, Dittmar MT, Simmons G, Bell J, Simmonds P, Clapham PR: Biological analysis of human immunodeficiency virus type 1 R5 envelopes amplified from brain and 
lymph node tissues of AIDS patients with neuropathology reveals two distinct tropism phenotypes and identifies envelopes in the brain that confer an enhanced tropism and fusigenicity for macrophages. J Virol 2004, 78:6915-6926.

8. Evers S, Rahmann A, Schwaag S, Frese A, Reichelt D, Husstedt IW: Prevention of AIDS dementia by HAART does not depend on cerebrospinal fluid drug penetrance. AIDS Res Hum Retroviruses 2004 20:483-491.

9. Letendre S, Marquie-Beck J, Capparelli E, Best B, Clifford D, Collier AC, Gelman BB, McArthur JC, McCutchan JA, Morgello S, Simpson D, Grant I, Ellis RJ, CHARTER Group: Validation of the CNS Penetration-Effectiveness rank for quantifying antiretroviral penetration into the central nervous system. Arch Neurol 2008, 65:65-70.

10. Davis $L E$, Hjelle BL, Miller VE, Palmer DL, Llewellyn AL, Merlin TL, Young SA Mills RG, Wachsman W, Wiley CA: Early viral brain invasion in iatrogenic human immunodeficiency virus infection. Neurology 1992, 42:1736-1739.

11. Hult B, Chana G, Masliah E, Everall I: Neurobiology of HIV. Int Rev Psychiatry 2008, 20:3-13.

12. Nottet HS, Persidsky Y, Sasseville VG, Nukuna AN, Bock P, Zhai QH, Sharer LR, McComb RD, Swindells S, Soderland C, Gendelman HE: Mechanisms for the transendothelial migration of HIV-1-infected monocytes into brain. J Immunol 1996, 156:1284-1295.

13. Buckner CM, Calderon TM, Willams DW, Belbin TJ, Berman JW: Characterization of monocyte maturation/differentiation that facilitates their transmigration across the blood-brain barrier and infection by HIV: implications for NeuroAIDS. Cell Immunol 2011, 267:109-123.

14. Wang $\mathrm{H}$, Sun J, Goldstein H: Human immunodeficiency virus type 1 infection increases the in vivo capacity of peripheral monocytes to cross the blood-brain barrier into the brain and the in vivo sensitivity of the blood-brain barrier to disruption by lipopolysaccharide. J Virol 2008 82:7591-7600

15. Pu H, Hayashi K, Andras IE, Eum SY, Hennig B, Toborek M: Limited role of COX-2 in HIV Tat-induced alterations of tight junction protein expression and disruption of the blood-brain barrier. Brain Res 2007, 1184:333-344.

16. Kaul M, Garden GA, Lipton SA: Pathways to neuronal injury and apoptosis in HIV-associated dementia. Nature 2001, 410:988-994.

17. Koenig S, Gendelman HE, Orenstein JM, Dal Canto MC, Pezeshkpour GH, Yungbluth M, Janotta F, Aksamit A, Martin MA, Fauci AS: Detection of AIDS virus in macrophages in brain tissue from AIDS patients with encephalopathy. Science 1986, 233:1089-1093.

18. Gorry PR, Bristol G, Zack JA, Ritola K, Swanstrom R, Birch CJ, Bell JE, Bannert N, Crawford K, Wang H, Schols D, De Clercq E, Kunstman K, Wolinsky SM, Gabuzda D: Macrophage tropism of human immunodeficiency virus type 1 isolates from brain and lymphoid tissues predicts neurotropism independent of coreceptor specificity. J Virol 2001, 75:10073-10089.

19. Churchill MJ, Wesselingh SL, Cowley D, Pardo CA, McArthur JC, Brew BJ, Gorry PR: Extensive astrocyte infection is prominent in human immunodeficiency virus-associated dementia. Ann Neurol 2009, 66:253-258.

20. Wang T, Gong N, Liu J, Kadiu I, Kraft-Terry SD, Schlautman JD, Ciborowski P, Volsky DJ, Gendelman HE: HIV-1-infected astrocytes and the microglial proteome. J Neuroimmune Pharmacol 2008, 3:173-186.

21. Singh RK, Gupta S, Dastidar S, Ray A: Cysteinyl leukotrienes and their receptors: molecular and functional characteristics. Pharmacology 2010, 85:336-349.

22. Ciana P, Fumagalli M, Trincavelli ML, Verderio C, Rosa P, Lecca D, Ferrario S, Parravicini C, Capra V, Gelosa P, Guerrini U, Belcredito S, Cimino M, Sironi L, Tremoli E, Rovati GE, Martini C, Abbracchio MP: The orphan receptor GPR17 identified as a new dual uracil nucleotides/cysteinyl-leukotrienes receptor. EMBO J 2006, 25:4615-4627.

23. Kato K, Yokomizo T, Izumi T, Shimizu T: Cell-specific transcriptional regulation of human leukotriene $\mathrm{B}(4)$ receptor gene. J Exp Med 2000, 192:413-420

24. Yokomizo T, Kato $K$, Terawaki $K$, Izumi T, Shimizu T: A second leukotriene $B$ (4) receptor, BLT2. A new therapeutic target in inflammation and immunological disorders. J Exp Med 2000, 192:421-432.

25. Kanaoka Y, Boyce JA: Cysteinyl leukotrienes and their receptors: cellular distribution and function in immune and inflammatory responses. $J$ Immunol 2004, 173:1503-1510.
26. Ballerini P, Di lorio P, Ciccarelli R, Caciagli F, Poli A, Beraudi A, Buccella $S$, D'Alimonte I, D'Auro M, Nargi E, Patricelli P, Visini D, Traversa U: P2Y1 and cysteinyl leukotriene receptors mediate purine and cysteinyl leukotriene co-release in primary cultures of rat microglia. Int I Immunopathol Pharmacol 2005, 18:255-268.

27. Okubo M, Yamanaka H, Kobayashi K, Noguchi K: Leukotriene synthases and the receptors induced by peripheral nerve injury in the spinal cord contribute to the generation of neuropathic pain. Glia 2010, 58:599-610.

28. Lammers CH, Schweitzer P, Facchinetti P, Arrang JM, Madamba SG, Siggins GR, Piomelli D: Arachidonate 5-lipoxygenase and its activating protein: prominent hippocampal expression and role in somatostatin signaling. J Neurochem 1996, 66:147-152.

29. Matsuo M, Hamasaki Y, Fujiyama F, Miyazaki S: Eicosanoids are produced by microglia, not by astrocytes, in rat glial cell cultures. Brain Res 1995, 685:201-204.

30. Hui Y, Funk CD: Cysteinyl leukotriene receptors. Biochem Pharmacol 2002, 64:1549-1557.

31. Zhang WP, Hu H, Zhang L, Ding W, Yao HT, Chen KD, Sheng WW, Chen Z Wei EQ: Expression of cysteinyl leukotriene receptor 1 in human traumatic brain injury and brain tumors. Neurosci Lett 2004, 363:247-251.

32. Mayatepek E: Leukotriene C4 synthesis deficiency: a member of a probably underdiagnosed new group of neurometabolic diseases. Eur $J$ Pediatr 2000, 159:811-818.

33. Heise CE, O'Dowd BF, Figueroa DJ, Sawyer N, Nguyen T, Im DS, Stocco R, Bellefeuille JN, Abramovitz M, Cheng R, Williams DL Jr, Zeng Z, Liu Q, Ma L, Clements MK, Coulombe N, Liu Y, Austin CP, George SR, O'Neill GP, Metters KM, Lynch KR, Evans JF: Characterization of the human cysteinyl leukotriene 2 receptor. J Biol Chem 2000, 275:30531-30536.

34. Hu H, Chen G, Zhang JM, Zhang WP, Zhang L, Ge QF, Yao HT, Ding W, Chen Z, Wei EQ: Distribution of cysteinyl leukotriene receptor 2 in human traumatic brain injury and brain tumors. Acta Pharmacol $\sin 2005$, 26:685-690.

35. Lecca D, Trincavelli ML, Gelosa P, Sironi L, Ciana P, Fumagalli M, Villa G, Verderio C, Grumelli C, Guerrini U, Tremoli E, Rosa P, Cuboni S, Martini C, Buffo A, Cimino M, Abbracchio M: The recently identified P2Y-like receptor GPR17 is a sensor of brain damage and a new target for brain repair. PLoS One 2008, 3:e3579.

36. Genis P, Jett M, Bernton EW, Boyle T, Gelbard HA, Dzenko K, Keane RW, Resnick L, Mizrachi Y, Volsky DJ, Epstein LG, Gendelman HE: Cytokines and arachidonic metabolites produced during human immunodeficiency virus (HIV)-infected macrophage-astroglia interactions: implications for the neuropathogenesis of HIV disease. J Exp Med 1992, 176:1703-1718.

37. Froldi M, Castagna A, Parma M, Piona A, Tedeschi A, Miadonna A, Lorini M, Orazio EN, Lazzarin A: Mediator release in cerebrospinal fluid of human immunodeficiency virus-positive patients with central nervous system involvement. J Neuroimmunol 1992, 38:155-161.

38. Basselin M, Ramadan E, lgarashi M, Chang L, Chen M, Kraft AD, Harry GJ, Rapoport SI: Imaging upregulated brain arachidonic acid metabolism in HIV-1 transgenic rats. J Cereb Blood Flow Metab 2011, 31:486-493.

39. Rao JS, Kim HW, Kellom M, Greenstein D, Chen M, Kraft AD, Harry GJ, Rapoport SI, Basselin M: Increased neuroinflammatory and arachidonic acid cascade markers, and reduced synaptic proteins, in brain of HIV-1 transgenic rats. J Neuroinflammation 2011, 8:101.

40. Albright AV, Gonzalez-Scarano F: Microarray analysis of activated mixed glial (microglia) and monocyte-derived macrophage gene expression. $J$ Neuroimmunol 2004, 157:27-38.

41. Aloisi F: Immune function of microglia. Glia 2001, 36:165-179.

42. Ghorpade A, Persidsky Y, Swindells S, Borgmann K, Persidsky R, Holter S, Cotter R, Gendelman HE: Neuroinflammatory responses from microglia recovered from HIV-1-infected and seronegative subjects. J Neuroimmunol 2005, 163:145-156.

43. Wu DT, Woodman SE, Weiss JM, McManus CM, D'Aversa TG, Hesselgesser J, Major EO, Nath A, Berman JW: Mechanisms of leukocyte trafficking into the CNS. J Neurovirol 2000, 6(Suppl 1):S82-S85.

44. Flamand L, Borgeat P, Lalonde R, Gosselin J: Release of anti-HIV mediators after administration of leukotriene B4 to humans. J Infect Dis 2004, 189:2001-2009

45. Flamand L, Tremblay MJ, Borgeat P: Leukotriene B4 triggers the in vitro and in vivo release of potent antimicrobial agents. J Immunol 2007, 178:8036-8045. 
46. Li Y, Hui H, Burgess CJ, Price RW, Sharp PM, Hahn BH, Shaw GM: Complete nucleotide sequence, genome organization, and biological properties of human immunodeficiency virus type 1 in vivo: evidence for limited defectiveness and complementation. J Virol 1992, 66:6587-6600.

47. Li Y, Kappes JC, Conway JA, Price RW, Shaw GM, Hahn BH: Molecular characterization of human immunodeficiency virus type 1 cloned directly from uncultured human brain tissue: identification of replication-competent and -defective viral genomes. J Virol 1991, 65:3973-3985.

48. Dornadula G, Zhang H, Shetty S, Pomerantz RJ: HIV-1 virions produced from replicating peripheral blood lymphocytes are more infectious than those from nonproliferating macrophages due to higher levels of intravirion reverse transcripts: implications for pathogenesis and transmission. Virology 1999, 253:10-16.

49. Fortin JF, Cantin R, Lamontagne G, Tremblay M: Host-derived ICAM-1 glycoproteins incorporated on human immunodeficiency virus type 1 are biologically active and enhance viral infectivity. J Virol 1997, 71:3588-3596.

50. Bounou S, Leclerc JE, Tremblay MJ: Presence of host ICAM-1 in laboratory and clinical strains of human immunodeficiency virus type 1 increases virus infectivity and CD4(+)-T-cell depletion in human lymphoid tissue, a major site of replication in vivo. J Virol 2002, 76:1004-1014.

51. Steckbeck JD, Orlov I, Chow A, Grieser H, Miller K, Bruno J, Robinson JE, Montelaro RC, Cole KS: Kinetic rates of antibody binding correlate with neutralization sensitivity of variant simian immunodeficiency virus strains. J Virol 2005, 79:12311-12320.

52. Zack JA, Arrigo SJ, Weitsman SR, Go AS, Haislip A, Chen IS: HIV-1 entry into quiescent primary lymphocytes: molecular analysis reveals a labile, latent viral structure. Cell 1990, 61:213-222.

53. Suzuki Y, Misawa N, Sato C, Ebina H, Masuda T, Yamamoto N, Koyanagi Y: Quantitative analysis of human immunodeficiency virus type 1 DNA dynamics by real-time PCR: integration efficiency in stimulated and unstimulated peripheral blood mononuclear cells. Virus Genes 2003, 27:177-188.

54. Chun TW, Stuyver L, Mizell SB, Ehler LA, Mican JA, Baseler M, Lloyd AL, Nowak MA, Fauci AS: Presence of an inducible HIV-1 latent reservoir during highly active antiretroviral therapy. Proc Natl Acad Sci USA 1997, 94:13193-13197.

55. Leone C, Le Pavec G, Meme W, Porcheray F, Samah B, Dormont D, Gras G Characterization of human monocyte-derived microglia-like cells. Glia 2006, 54:183-192.

56. Mildner A, Schmidt H, Nitsche M, Merkler D, Hanisch UK, Mack M, Heikenwalder M, Bruck W, Priller J, Prinz M: Microglia in the adult brain arise from Ly-6ChiCCR2+ monocytes only under defined host conditions. Nat Neurosci 2007, 10:1544-1553.

57. Noto D, Takahashi K, Miyake S, Yamada M: In vitro differentiation of lineage-negative bone marrow cells into microglia-like cells. Eur J Neurosci 2010, 31:1155-1163.

58. Ito D, Imai Y, Ohsawa K, Nakajima K, Fukuuchi Y, Kohsaka S: Microgliaspecific localisation of a novel calcium binding protein, lba1. Brain Res Mol Brain Res 1998, 57:1-9.

59. Bailie MB, Standiford TJ, Laichalk LL, Coffey MJ, Strieter R, Peters-Golden M: Leukotriene-deficient mice manifest enhanced lethality from Klebsiella pneumonia in association with decreased alveolar macrophage phagocytic and bactericidal activities. J Immunol 1996, 157:5221-5224.

60. Feinmark SJ, Lindgren JA, Claesson HE, Malmsten C, Samuelsson B: Stimulation of human leukocyte degranulation by leukotriene B4 and its omega-oxidized metabolites. FEBS Lett 1981, 136:141-144.

61. Foster A, Fitzsimmons B, Letts LG: The synthesis of $N$-acetyl-leukotriene E4 and its effects on cardiovascular and respiratory function of the anesthetized pig. Prostaglandins 1986, 31:1077-1086.

62. Warrilow D, Gardner J, Darnell GA, Suhrbier A, Harrich D: HIV type 1 inhibition by protein kinase $C$ modulatory compounds. AIDS Res Hum Retroviruses 2006, 22:854-864.

63. Thivierge M, Le Gouill C, Tremblay MJ, Stankova J, Rola-Pleszczynski M: Prostaglandin E2 induces resistance to human immunodeficiency virus-1 infection in monocyte-derived macrophages: downregulation of CCR5 expression by cyclic adenosine monophosphate. Blood 1998, 92:40-45.

64. Hayes MM, Lane BR, King SR, Markovitz DM, Coffey MJ: Prostaglandin E(2) inhibits replication of HIV-1 in macrophages through activation of protein kinase A. Cell Immunol 2002, 215:61-71.
65. Boisvert M, Cote S, Vargas A, Pasvanis S, Bounou S, Barbeau B, Dumais N: PGJ2 antagonizes NF-kappaB-induced HIV-1 LTR activation in colonic epithelial cells. Virology 2008, 380:1-11.

66. Kalantari P, Narayan V, Henderson AJ, Prabhu KS: 15-Deoxy-Delta12,14prostaglandin $\mathrm{J} 2$ inhibits HIV-1 transactivating protein, Tat, through covalent modification. FASEB J 2009, 23:2366-2373.

67. Malaviya R, Abraham SN: Role of mast cell leukotrienes in neutrophil recruitment and bacterial clearance in infectious peritonitis. J Leukoc Biol 2000, 67:841-846.

68. Demitsu T, Katayama H, Saito-Taki T, Yaoita H, Nakano M: Phagocytosis and bactericidal action of mouse peritoneal macrophages treated with leukotriene B4. Int J Immunopharmacol 1989, 11:801-808.

69. Medeiros Al, Sa-Nunes A, Soares EG, Peres CM, Silva CL, Faccioli LH: Blockade of endogenous leukotrienes exacerbates pulmonary histoplasmosis. Infect Immun 2004, 72:1637-1644.

70. Chen N, Restivo A, Reiss CS: Leukotrienes play protective roles early during experimental VSV encephalitis. J Neuroimmunol 2001, 120:94-102.

71. Cherrier T, Suzanne S, Redel L, Calao M, Marban C, Samah B, Mukerjee R, Schwartz C, Gras G, Sawaya BE, Zeichner SL, Aunis D, Van Lint C, Rohr O: p21(WAF1) gene promoter is epigenetically silenced by CTIP2 and SUV39H1. Oncogene 2009, 28:3380-3389.

72. Owman C, Garzino-Demo A, Cocchi F, Popovic M, Sabirsh A, Gallo RC: The leukotriene $B 4$ receptor functions as a novel type of coreceptor mediating entry of primary HIV-1 isolates into CD4-positive cells. Proc Natl Acad Sci USA 1998, 95:9530-9534.

73. Martin $V$, Ronde $P$, Unett $D$, Wong A, Hoffman $T L$, Edinger AL, Doms RW, Funk CD: Leukotriene binding, signaling, and analysis of HIV coreceptor function in mouse and human leukotriene B4 receptor-transfected cells. J Biol Chem 1999, 274:8597-8603.

74. Lehmann-Che J, Saib A: Early stages of HIV replication: how to hijack cellular functions for a successful infection. AIDS Rev 2004, 6:199-207.

75. Sherman MP, Greene WC: Slipping through the door: HIV entry into the nucleus. Microbes Infect 2002, 4:67-73.

76. Arhel NJ, Souquere-Besse S, Munier S, Souque P, Guadagnini S, Rutherford S, Prevost MC, Allen TD, Charneau P: HIV-1 DNA Flap formation promotes uncoating of the pre-integration complex at the nuclear pore. EMBO J 2007, 26:3025-3037.

77. Krishnan L, Matreyek KA, Oztop I, Lee K, Tipper CH, Li X, Dar MJ, Kewalramani VN, Engelman A: The requirement for cellular transportin 3 (TNPO3 or TRN-SR2) during infection maps to human immunodeficiency virus type 1 capsid and not integrase. J Virol 2010, 84:397-406.

78. Christ F, Thys W, De Rijck J, Gijsbers R, Albanese A, Arosio D, Emiliani S, Rain JC, Benarous R, Cereseto A, Debyser Z: Transportin-SR2 imports HIV into the nucleus. Curr Biol 2008, 18:1192-1202.

79. Thys W, De Houwer S, Demeulemeester J, Taltynov O, Vancraenenbroeck R, Gerard M, De Rijck J, Gijsbers R, Christ F, Debyser Z: Interplay between HIV entry and transportin-SR2 dependency. Retrovirology 2011, 8:7.

80. Kehlenbach RH, Gerace L: Phosphorylation of the nuclear transport machinery down-regulates nuclear protein import in vitro. $J$ Biol Chem 2000, 275:17848-17856.

doi:10.1186/1742-2094-9-55

Cite this article as: Bertin et al:: Leukotrienes inhibit early stages of HIV-

1 infection in monocyte-derived microglia-like cells. Journal of

Neuroinflammation 2012 9:55.

\section{Submit your next manuscript to BioMed Central and take full advantage of:}

- Convenient online submission

- Thorough peer review

- No space constraints or color figure charges

- Immediate publication on acceptance

- Inclusion in PubMed, CAS, Scopus and Google Scholar

- Research which is freely available for redistribution 